Meta

Journal des traducteurs

Translators' Journal

\title{
A Thing-bound Approach to the Practice and Teaching of Technical Translation
}

\section{Barbara Folkart}

Volume 29, numéro 3, septembre 1984

URI : https://id.erudit.org/iderudit/002751ar

DOI : https://doi.org/10.7202/002751ar

Aller au sommaire du numéro

\section{Éditeur(s)}

Les Presses de l'Université de Montréal

ISSN

0026-0452 (imprimé)

1492-1421 (numérique)

Découvrir la revue

Citer cet article

Folkart, B. (1984). A Thing-bound Approach to the Practice and Teaching of Technical Translation. Meta, 29(3), 229-246. https://doi.org/10.7202/002751ar

\section{Résumé de l'article}

The raison d'être of the technical text is in the access it affords to its referents. It follows that technical translation involves reverbalizing these referents rather than mapping semiotic structures from source-to target-language, as is the case with the other, more "hybrid" forms of discourse, in which functions of language other than the purely referential play a role. The source-language formulation is thus relatively unimportant. In the extreme case, which is not necessarily that of a poorly written source text, it can even be bypassed altogether, the translator drawing his information from the non-linguistic segments of the source text (equations, diagrams and the like) and verbalizing it directly in the target language.For Ivan Hirst, from whom I learned most of what I know about technical translation. The technical translator's stock in trade is an in-depth understanding of the referent. The following article proposes a number of teaching strategies designed to sensitize non-specialist students to the importance of the referent, to help them acquire the minimal background they will need to deal with texts in a given field and to enable them to reduce technical texts to their underlying referents.
Ce document est protégé par la loi sur le droit d'auteur. L’utilisation des services d'Érudit (y compris la reproduction) est assujettie à sa politique d'utilisation que vous pouvez consulter en ligne.

https://apropos.erudit.org/fr/usagers/politique-dutilisation/ 


\section{A THING-BOUND APPROACH TO THE PRACTICE AND TEACHING OF TECHNICAL TRANSLATION}

BARBARA FOLKART

For Ivan Hirst, from whom I learned most of what 1 know about technical translation.

\section{ABSTRACT}

The raison d'être of the technical text is in the access it affords to its referents. It follows that technical translation involves reverbalizing these referents rather than mapping semiotic structures from source-to target-language, as is the case with the other, more "hybrid" forms of discourse, in which functions of language other than the purely referential play a role.

The source-language formulation is thus relatively unimportant. In the extreme case, which is not necessarily that of a poorly written source text, it can even be bypassed altogether, the translator drawing his information from the non-linguistic segments of the source text (equations, diagrams and the like) and verbalizing it directly in the target language.

The technical translator's stock in trade is an in-depth understanding of the referent. The following article proposes a number of teaching strategies designed to sensitize non-specialist students to the importance of the referent, to help them acquire the minimal background they will need to deal with texts in a given field and to enable them to reduce technical texts to their underlying referents.

\section{GENERAL CONSIDERATIONS}

Technical discourse is the manifestation par excellence of the referential function of language 1 . As opposed to potic discourse, which tends to the limit of maximum opacity, the technical text is, ideally, transparent ${ }^{2}$. This dichotomy has some very fundamental implications for the translation process. Since the potic text is a linguistic object in its own right, one whose formal, phonetic and allusive sructures are invested with meaning independently of any reference to the extralinguistic, the pœtic translation tra-

1. For a more detailed treatment of this question, see my article on " $L$ 'enseignement de la traduction technique : une approche formelle du discours technique", The University of Ottawa Quarterly, vol. $51, \mathrm{n}^{\circ} 3$ : 505-521.

2. The terms "opacity" and "transparency", as I use them, refer to the relationship between sign and referent. In its transparent uses, the sign affords immediate access to the referent, for which it is merely a "stand-in"; the sign becomes opaque - or self-referential — in utterances (" rose rhymes avec nose", "'The Chief' is here") which call attention to either its signifier or its signified, either totally or partially at the expense of its reference. 
jectory will be from the surface to the semiotic structures and thence to the target text. In technical translation, on the other hand, the appropriate trajectory will be from source language to extralinguistic referent to target language, or even, in certain limiting cases, from referent to target language, bypassing, so to speak, the source text. Essentially, then, the process of technical translation involves apprehending the extralinguistic referents verbalized by the source text and re-verbalizing them, more or less directly (i.e. more or less independently of the source text), in the target language. tion :

This has several implications for the practice and teaching of technical transla-

Most obviously, knowledge of the referent is the condition sine qua non of technical translation : the technical translator's stock in trade is some sort of background in the actual domain under consideration or, lacking this, the ability to build up artificially - and rapidly - a competency approaching that of the specialist reader for whom the source-text was written in the first place.

Secondly, transparency - i.e., immediacy of access to the referent - is the only feature of the source text qua text that need be preserved in translation. This of course subsumes the transposition of registral features : the target-text, like the source-text, will be transparent only to the extent that it is congruent with the reader's expectations of what a technical text should be ; as soon as it departs from the expected technical registrer, it draws attention to itself, with a resulting loss of transparency. Within the technical register appropriate to the subject, however, the translator has considerable latitude in reverbalizing in the target language the referents he has apprehended through the source-text. Thus, the following sentence, describing, concurrently with a diagram, a specific feature of masonry vaults :

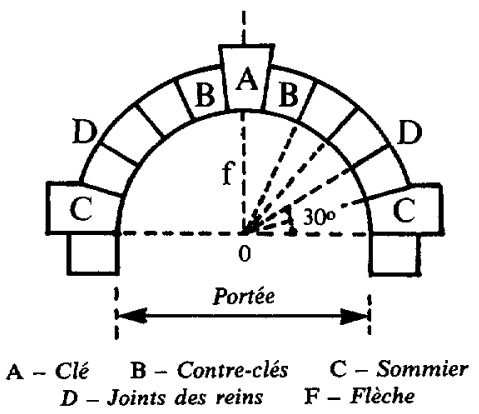

Les joints convergent tous vers le centre et sont donc perpendiculaires à la surface de la douelle. (Quillet-Bâtiment II : 302.)

can be rendered as :

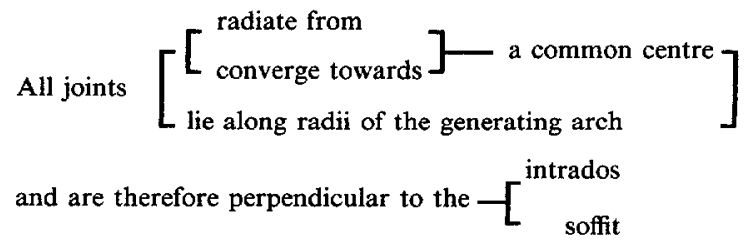

all of which are accurate descriptions of the referent and as such equally acceptable. 
In certain cases, the target text, or segments of it, may be a (re-)verbalisation, not of the source-text itself, but of the information conveyed concurrently by non-linguistic texts interacting more or less redundantly with it - typographical layout, equations, diagrams and the like - which are saying much the same thing at the same time as the linguistic text. The degree of redundancy between linguistic and non-linguistic segments varies considerably, the limiting case being that of mathematical texts in which symbolic phrases/sentences generate their own verbal equivalents quasi-automatically and may overlap so completely with the linguistic text in which they are embedded as to be isomorphic to $\mathrm{it}^{3}$. In the following text :

$D$ 'une manière générale, le complémentaire d'un ensemble $X$ par rapport à un ensemble $Y$, $X \subset Y$, est l'ensemble des éléments de $Y$ qui n'appartiennent pas à $X$. On le note : $\mathrm{C}_{\mathrm{y}} \mathrm{X}=\{\mathrm{X} \mid \mathrm{X} \subset \mathrm{Y}, \mathrm{x} \not \subset \mathrm{X}\}$.

there is a one-to-one correspondance between linguistic and symbolic syntagmata : le complémentaire d'un ensemble $X$ par rapport $\grave{a}$ un ensemble $\mathbf{Y}$ est l'ensemble (des) éléments de $Y$ qui n'appartiennent pas à $X$

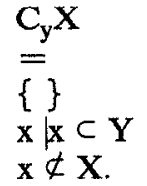

Even when the interaction between linguistic and non-linguistic texts is not so pronounced, it may nevertheless be significant enough to offer alternative avenues of approach to the referent. Thus the English renderings quoted above (Quillet-Bâtiment II : 302) can be derived indifferently from the French text or from the diagram accompanying it. As means of access to the referent, all these systems are on a more or less equal footing, and there is no reason a priori for the translator to privilege systematically the linguistic text over its symbolic and graphic counterparts.

Yet another area in which the predominantly referential character of technical discourse has decisive implications for the theory, practice and teaching of translation is terminology. Technical terminologies are mere nomenclatures, systems of labels used purely to designate the extra-linguistic entities with which they entertain a generally one-to-one relationship (as they often do with the corresponding terminologies in other languages). As such, they form "externally" structured lexical fields, ones which reflect the ordering of the referents they have been constructed to designate rather than exhibiting the sort of internal structuring characteristic of "true" lexical signs and accessible only through componential analysis ${ }^{4}$. Thus for example, the fields constituted by the designations of machine parts (consider the sub-field gear, cam, shaft, valve, housing,

3. In such cases, there is a high probability that the target text will also be isomorphic to the equations, and hence to the source-language segments verbalizing them.

4. The technical term, like the referent for which it is a substitute, is a "manufactured" item (cf. Pinchuk 1977 : 179, "A concept is first of all defined, and subsequently given a name") - and this holds true even when a general term is absorbed into a nomenclature. The referent is first defined as a bundle or rigourously relevant features, all of which are activated in every conceivable technical context, then a term is constructed ad hoc or borrowed to designate it.

It is for this reason that such nomenclatures are structured "externally", i.e. according to macroscopic, physically verifiable properties of their referents, rather than microscopically according to presumed universals of logic that can only be discerned through componential analysis and may be neutralized in certain contexts, as is the case of true lexical fields.

A case in point is the nomenclature descriptive of the machine parts diagramed as a tree below. Such parts are manufactured according to certain specifications to perform specific functions : as such they, like the terms which designate them, are actualisations of pre-existing bundles or relevant features, tokens of a pre-existing conceptual type. When one structures the terms representing the physical objects into trees, one is simply retreiving the conceptualisation that governs the manufacturing of such parts. 
piston-rod-crank assembly), like those referring to different types of automotive engine design ( $\mathbf{L}$ - or T-head, I-head, F-head ; in-block/overhead camshaft ; direct/indirect valve action) or of architectural vault (voûte en berceau, d'arêtes, en arc de cloître, for example) are structurable in terms of "relevant" features corresponding to physical properties - function, form or mode of operation - of the actual objects :

\section{machine parts \\ function}

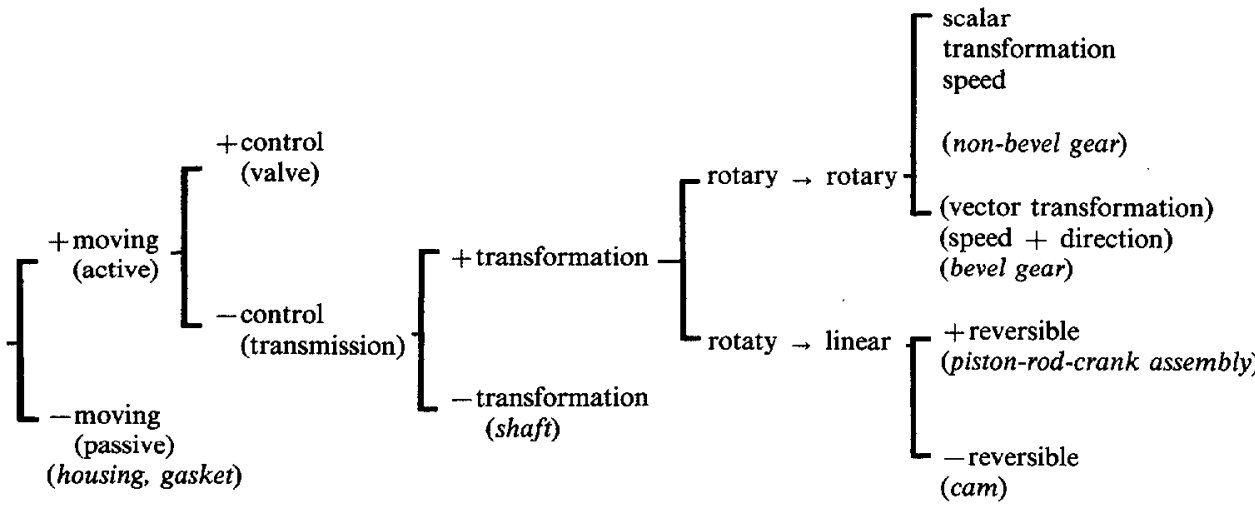

$$
\begin{gathered}
\text { vaults } \\
\text { form }+ \text { construction }
\end{gathered}
$$




automative timing systems type of layout

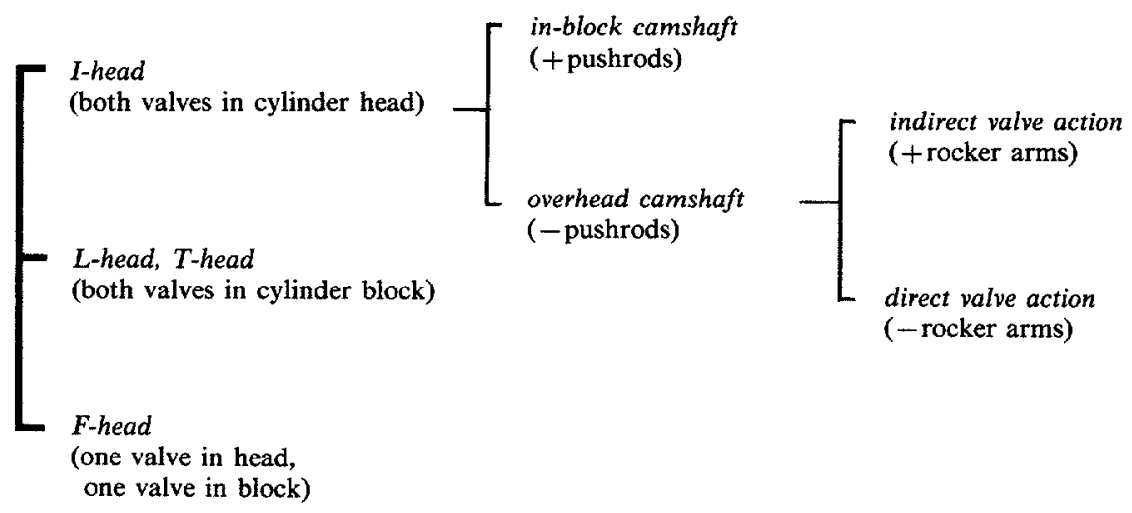

Since terminological items are mere stand-ins for the things they represent, knowledge of the referent and of the physical/extralinguistic relationships it entertains with the other objects in its field is indispensable when, as in fact happens, either the source language or the target language is deficient (exhibits gaps) or defective (includes terms having two or more distinct referents).

When voids occur because the one-to-one mapping between source-language and target-language nomenclatures has broken down, they may be dealt with either paraphrastically or metalinguistically. When the void is in the target-language, only the first leg of the translational trajectory from source-language term to referent to targetlanguage term can be completed : having gone from the source-language term to the thing, the translator cannot count on a ready-made relabelling to designate the latter in the target language. It is here that he must have a good operational understanding of the referent, one which will allow him to invent, as a target-language equivalent of the source-language item, a descriptive syntagma or paraphrase evolved from one of the possible sets of relevant features.

Consider, for example, in a description of the piston-connecting rod-crank assembly, the following sentence :

La manivelle, appelée aussi vilebrequin, est un arbre coudé qui peut tourner autour de l'axe Oz défini par ses deux tourillons. (Quillet-Mécanique : 153.)

The translator is confronted here with a series of three quasi-synonyms, each having a slightly different textual function : the term manivelle is used throughout the text to designate the elementary machine and thus represents the more general perspective of mechanics as a branch of physics ; the meta-linguistic segment appelée aussi vilebrequin refers to the specific actualisation of such elementary machines in devices like pumps or automotive engines ; the term arbre coudé refers to a fairly general class of actual physical objects characterized by a specific type of shape. The sentence as a whole thus describes the way in which the general, almost abstract type of elementary machine is im- 
plemented and designated in actual devices. In terms of the relevant features which differentiate them, manivelle, arbre coudé, et vilebrequin form a set of hyponyms structured as follows :

\begin{tabular}{lccc}
\hline & & $\begin{array}{c}\text { two cranks } \\
\text { joined to } \\
\text { act concur } \\
\text { rently }\end{array}$ & $\begin{array}{c}\text { part of } \\
\text { engine }\end{array}$ \\
\hline manivelle & crank & - & - \\
\hline arbre coudé & + & + & - \\
\hline vilebrequin & + & + & + \\
\hline
\end{tabular}

Now the problem confronting the translator is that two of the French hyponyms map over into a single English term, crankshaft : English seems to possess no term, such as *angled shaft, having the same extension as arbre coudé.

The translator will therefore have to deal with this particular segment of the source text by inventing a paraphrase describing the referent in terms of physical properties relevant to this particular context. He may thus render the sentence as ${ }^{5}$ :

$\begin{array}{ll}\text { The crank, } & \text { or "crankshaft", } \\ \text { elementary } & \text { self-referential } \\ \text { machine } & \text { segment; name of } \\ & \text { crank as imple- } \\ & \text { mented in actual } \\ & \text { engines, etc. }\end{array}$

consists of a throw 5 turning a shaft
gloss, descriptive paraphrase of arbre coudé engines, etc.

which is free to rotate about the axis $\mathrm{Oz}$ defined by its two journals.

This type of translational itinerary seems to be quite productive in technical writing also : the authors of a road-test report on the Pontiac $J 2000$ published in the Quebec Review Protégez-vous (January, 1982 : 60) clearly used the same procedure to designate the fairly recent technological innovation known in English as a "lockup converter", a term for which there seems to be as yet no standard equivalent in French ${ }^{6}$. Recognizing this component to be one in which impeller and turbine are made to lock together, clutch-like, above a certain speed to eliminate slippage, Protégez-vous's writers came up with the descriptive paraphrase convertisseur de couple avec embrayage to fill the gap.

In the rendering of metalinguistically oriented texts such as the following :

Les massifs d'appuis s'appellent des piédroits quand ils ne reçoivent que des charges verticales (cas du massif commun à deux voûtes contiguës). Dans le cas des grandes voûtes des ponts ils s'appellent des piles. S'ils reçoivent aussi des charges horizontales ce sont des culées (cas du massif ne recevant qu'une voûte). (Quillet-Bâtiment II : 302.)

5. Normally : "a series of throws", but the authors of the original are limiting their considerations to the subassembly or individual "cell" formed by a single piston, connecting rod and crankpin.

6. The term is not included in the Office de la langue française's Terminologie de l'automobile, vol. I, le Moteur. 
the existence of terminological voids may turn the target text into a commentary on specific aspects of differential terminology. The sentence :

Dans le cas des grandes voûtes des ponts les massifs d'appui s'appellent des piles

cannot be translated directly, since the feature " + pont" is not relevant in English ; it can only be deleted altogether or replaced, in the target text, possibly as a footnote, by a sentence calling attention to this particularity of French terminology :

French terminology differentiates the supporting structures of bridges (piles) from those of other structures (piédroits) ; in English, the term pier is used whether or not the structural element is part of bridge.

When the void is in the source language, the translator may either comment on it metalinguistically or simply supply, with their target-language designations, the referential features missing in the source text. If, for example, the content of the text just dealt with had been formulated originally in English as :

The supports are termed piers when they carry a vertical load only (as between two adjacent vaults). When they carry a horizontal component as well (as when they support only one vault), they are know as abutments,

the translator into French would have the option of supplying the additional information and commenting on the difference between French and English nomenclatures or of merely supplying the additional information with no metalinguistic commentary (precisely as in the text published in Quillet-Bâtiment).

While voids or deficiencies occur because source and target-language terminologies are no longer in one-to-one correspondance, defects result when the one-to-one relationship between terms and referents breaks down. Here again, recourse to the referent is indispensable. To borrow an exemple from the French vocabulary of historical architecture, there is considerable fluctuation in the use of the terms surhaussé, surélevé and ogive, as applied to arches and vaults. Despite attemps by the French ministère des Affaires culturelles to codify the use of these terms ${ }^{7}$, ogive is widely used, even in fairly technical texts, to designate arches and vaults having a pointed section, whereas surhaussé is used very commonly to designate either
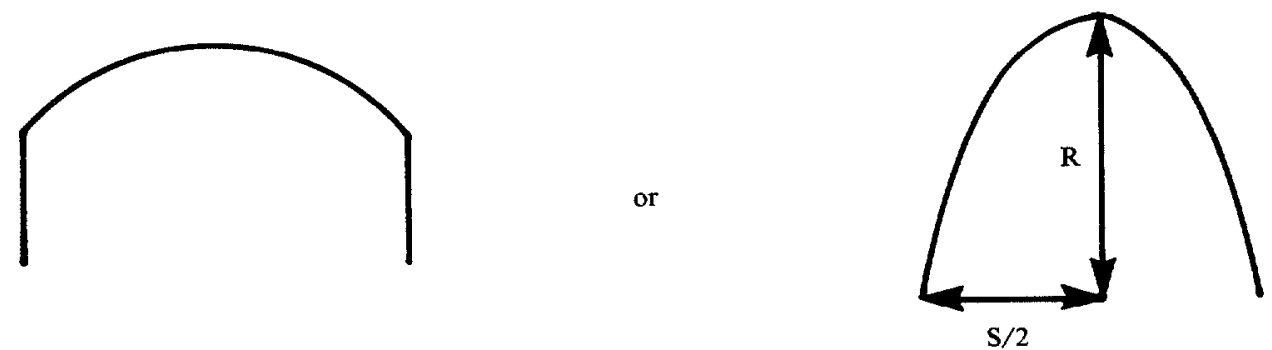

where $\mathrm{R}>\mathrm{S} / 2$

7. The rigourous and exhaustive Architecture : méthode et vocabulaire put out by the Ministère (Paris, Imprimerie nationale, 1972) gives the following definitions, complete with mise en garde : [Arc plein-cintre] ... On nomme ARC SURBAISSÉ tout arc dont la flèche est inférieure à la moitié de la portée et ARC SURHAUSSÉ tout arc dont la flèche est supérieure à la moitié de la portée. Ne pas confondre l'arc surhaussé avec l'arc surélevé (vol. I, col. 131).

Arc surélevé. Arc de tracé quelconque dont les naissances sont portées au-dessus du couronnement des piédroits ou des supports par des RETOMBÉES VERTICALES: un arc ne peut donc être surélevé que si le support a un couronnement (imposte, abaque, tailloir, etc.)... Ne pas confondre l'arc surélevé avec l'arc surhaussé (ibid, col. 133). 
i.e. an arch on stilts or an arch whose rise is greater than half its span. The corresponding English terms, stilted and pointed, give rise to no such confusion, undoubtedly because they enter into an opposition which exhibits a much higher degree of motivation, since it mimics linguistically the presence or absence of the relevant feature \pm stilt :

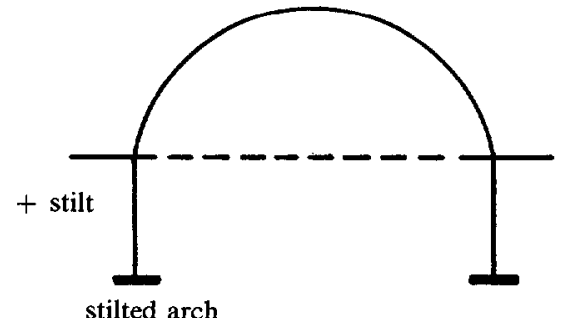

stilted arch

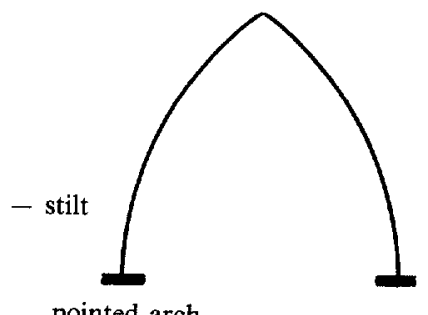

pointed arch

Clearly, then, it is essential that the translator visualize what the terms ogive and surhaussé are actually referring to in any specific text : once again, the correct technical translation procedure involves verbalizing referents rather than transcoding linguistic signs. Thus, a sentence such as the following :

La voûte en berceau peut elle-même être :

- surhaussée (ogive),

- plein-cintre (demi-cercle),

— surbaissée. (Quillet-Bâtiment II : 229.)

which contains "improper" occurrences of both surhaussé and ogive, together with an item, surbaissé, which seems to have no commonly used, univocal mapping into English ${ }^{8}$, cannot be translated correctly unless these items are perceived as forming a lexical sub-field designating a rigorously structured set of things. Here, it is the underlying geometric parameter (the ratio of the rise of the vault's profile to one-half its span) which structures the sub-field, and thus the passage, and which must be perceived if the text is to be correctly reverbalized in English. Only if the three terms are perceived as forming a system corresponding to the different values assumable by this parameter ( 1 , $1,1)$ can the ambiguity of polysemous terms such as surhaussé and ogive be resolved, allowing the text to be rendered as :

Barrel vaults are further subdivided according to whether their rise is :

- greater than half their span (pointed section)

- equal to half their span (round section)

- less than half their span.

Terminology is not the only area in which source language and target language may exhibit anisomorphisms that can be dealt with only by having recourse to the ex-

Ogive. Arc en nervure allant d'un point d'appui à un autre point d'appui en passant par la clef de voûte et remplaçant l'arête saillante que produirait la rencontre de deux quartiers ou de deux vốtains... Ne pas appeler ogive un arc brisé en couvrement, ou les arcs diagonaux d'une coupole nervurée (ibid., col. 154). Arc brisé. Arc à deux branches concaves se rejoignant en pointe au faîte... Ne pas appeler ogive l'arc brisé.

8. The Harrap's (1977) gives "depressed, flattened, surbased, segmental (arch, vault)" as the English equivalents of surbaissé, and "pointed (sic) obtuse arch, pointed (sic) segmental arch" for arc surbaissé. Comparison with the Penguin Dictionary of Architecture, however, reveals that the only one of these terms compatible with the use of surbaissé as codified by the ministère des Affaires culturelles (see note 7 above) is "segmental arch", which is defined as "a segment of a circle drawn from a centre below the springing line" (1980 edition, p. 17a) or as "having the profile of a circular arch substantially less than a full circle" (1980, p. 294a). 
tra-linguistic. Such differences in structure may surface in the form of 1) case gaps requiring explicitation and 2) syntactically equivocal segments.

When the source text contains elliptical formulations such as nominalisations, the translation process invariably involves explicitation. This requires, by definition, that the translator be able to supply, from his knowledge of the extra-linguistic, information that is only implicit in the source text. Sometimes such explicitation surfaces in the end product. Consider the following passage, dealing with overhead-valve (I-head) engine design as part of an exhaustive review of valve-train configurations :

Sur les moteurs à soupapes en tête (overhead valve engine, OVH engine, valve-in-head engine, I-head engine), les soupapes sont disposées dans la culasse, la queue dirigée vers le haut, en sens opposé de l'embiellage. Grâce à cette disposition, l'admission et l'échappement des gaz sont directs. Le remplissage des cylindres se fait donc bien. Mais l'ouverture des soupapes appelle un mouvement de haut en bas pour ces dernières. Si l'arbre à cames se situe en dessous des queues de soupapes, dans le carter (crankcase) par exemple, il faut renvoyer vers le bas le mouvement rectiligne ascendant que produisent les cames. (J. Lethuillier, "Évolution de la distribution dans les moteurs à combustion intermittente", Meta, 27-3 : 307.)

The elliptical (and possibly plurireferential) syntagma l'admission et l'échappement des gaz sont directs requires a certain amount of expansion and clarification to render it meaningful in relation to the extra-linguistic situation and thus make it single-valued. It must be perceived referentially, in opposition to the situation obtaining in the L-head configuration discussed earlier in the text, where the path travelled by the fuel charge and exhaust is not a straight line. Only then can it be interpreted (the gases travel in a straight line, intake and outflow are unimpeded) and re-encoded (This layout allows unimpeded flow of fuel charge and exhaust or With this type of arrangement, incoming and outgoing gases have a shorter and more open path to travel) correctly.

Sometimes, however, as in the following case, where a nominalized form with agent deletion is rendered by a nominal with agent and object deletion :

le remplissage des cylindres se fait donc bien

thus facilitating aspiration (= remplissage)

and thus improves breathing (= remplissage + évacuation)

volumetric efficiency ( $\propto$ remplissage),

explicitation is confined to the translational process, more specifically to the intermediate stage where the referent is reconstituted with the full array of parameters (linguistic and situational) characterizing it. Even when it leaves no residue in the target text, which may in fact be characterized by a higher degree of implication, explicitation (reconstitution of the full complement of referential parameters) is arguably a necessary stage in the process of technical translation.

Concrete and detailed knowledge of the referent is also indispensable whenever the source text is syntactically equivocal. Such knowledge alone will enable the translator to decide, in the following text describing an automotive clutch, what the syntagma la pression des plateaux means referentially :

La pression des plateaux est assurée soit par un système de ressorts hélicoïdaux, soit par un ressort-diaphragme. (OLF, III : 7.)

and to render

Pressure is exerted through the plates by a set of coil springs or a diaphragm spring. So too in the following passage :

L'embrayage est un mécanisme, situé entre le moteur et la boîte de vitesses, qui se compose d'au moins deux surfaces parallèles en rotation, entrant en contact par frottement à l'aide de 
ressorts et qui sont reliées respectivement au vilebrequin et à l'arbre primaire de la boîte de vitesses (ibid.).

where the syntagma entrant en contact par frottement can be diagrammed as either

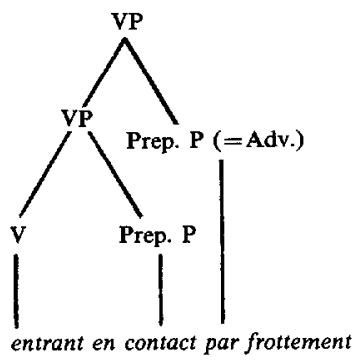

or

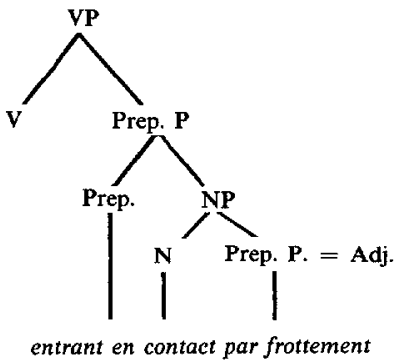

The first reading is more predictable from the linguistic standpoint, but is incompatible with the referential situation; the second, while linguistically less probable, gives a correct description of the referent and is thus to be preferred. In other words, extra-textual information is necessary if the text is to be decoded and re-encoded correctly :

[The clutch is a] mechanical device located between the engine and the gearbox and comprising at least two parallel rotating surfaces, one connected to the crankshaft, the other to the transmission input shaft, which are pressed into frictional contact by springs,

rather than :

... comprising at least two parallel rotating surfaces which are brought into contact by friction, using springs.

To summarize, then, translational invariance in technical discourse is strictly a matter of preserving the relationship of sign to referent. Whether the mapping from source language to target language involves a punctual segment (terminography) or an extended one (translation proper), specific linguistic or discursive features of the source text will be carried over into the target text only to the extent that they are referentially pertinent.

The latitude which the technical translator enjoys in producing a target-language equivalent of the source text is subject only to the constraints of register and, possibly, textual cohesion. The following passage, referring to the piston-connecting rod-crank assembly :

le système étant réversible, on l'utilisera tantôt dans le sens fluide moteur arbre récepteur (moteurs à explosion, machines à vapeur) tantôt dans l'autre sens (pompes, compresseurs). (Quillet-Mécanique : 153.)

should be rendered as :

The system is (thus) reversible, and can be operated with the fluid driving the (crank) shaft (internal combustion engines, steam engines) or the other way around (pumps, compressors). 
and not as :

Since the mechanism is reversible, it can be used to convert reciprocating to rotary motion (as in internal combustion engines, and steam engines) or to convert rotary to reciprocating motion (as in pumps and compressors).

The second rendering, although it gives a perfectly accurate account of the reversibility of the mechanism, an account which is based on a complementary and perfectly compatible set of features, is a less than adequate translation in as much as the decided shift in perspective entails a marked loss of textual cohesion. Whereas in the original there was an immediate and fairly explicit relationship between the way in which the mechanism was run and the type of practical applications to which it could give rise : fluide moteur - arbre récepteur $\leftrightarrow$ (moteurs à explosion machines à vapeur) arbre moteur - fluide récepteur $\leftrightarrow$ (pompes, compresseurs), this relationship with the material in parentheses is relegated to the status of an inference in the second rendering.

\section{A THING-BOUND STRATEGY FOR THE TEACHING OF TECHNICAL TRANSLATION}

Given the referentiality of technical discourse, our approach is predicated on the assumption that understanding of the referent is the single most important attribute of the technical translator. A systematic effort is made to show non-specialist students how they can build up background in a specific field. Considerable emphasis is placed on situation analysis : in a course dealing with texts on automotive engineering, a class may be devoted to a detailed discussion of the crankshaft, for example (function, form as dictated by function, related concepts of elementary mechanics). In addition to actual translations, a number of assignments are given with a view to forcing the student to deal with the concepts, things and linguistics of the field chosen for the course.

As an exploratory assignment students may be given a series of terms typical of the field chosen - e.g. terms designating basic automotive parts (gear, cam, shaft, valve, housing) and asked to define them as general machine parts (i.e. to find the relevant features common to all occurrences (tokens) of any given type), to indicate how they are used more specifically in automotive engineering and to illustrate them both visually, through appropriate documentation, and verbally, through typical contexts carefully chosen so as to be meaningful both referentially and linguistically (collocations, lexical fields). A similar exercise in a course dealing with historical architecture would involve terms such as simple/compound/barrel/groin/cloister/rib/vault (see Annex). The purpose of such an exercise is to familiarize students 1) with the referents and 2) with the way in which technical writers talk about these referents.

A considerable effort is made to present this material in a unifying perspective. Students are shown how the individual items they have dealt with can be integrated into sub-fields structurable in terms of the relevant features of their members (see trees on pages above). In the case of automotive parts (and no doubt of architectural elements) an explicit parallel can be drawn between machinery and language, machine parts forming functionally and distributionally defined paradigms which are in many ways analogous to the different distributionally and functionally defined categories of language, the machine itself being considered as a syntagma of interacting parts, i.e. as a text. This assignment, given at the very beginning of the course, is expected to provide students with the "machine grammar" - i.e. the understanding of mechanical paradigms and syntagmas - they will need throughout the course to deal with increasingly technical texts.

Another exercise designed to force students out of the purely linguistic mode of operating by making them come to grips with the referents behind the terms involves having them find iconographical equivalents to match specific items in the verbal texts 
they have been given to translate. This technique is particularly successful in texts dealing with historical architecture, where a verbal description of a nave or a narthex can be matched point by point to a plan, a passage dealing with decorative features (capitals, mouldings, etc.) to a photo.

Somewhat later on in the term, the students are given a test in which they are shown a drawing of, say, a major automotive assembly (valve train plus camshaft, crankshaft, or gearbox with its shift linkage) and asked to 1) label a certain number of parts, as an exercise in the recognition or relevant features (identification) even more than in terminology and 2) describe the functioning of this component, as an exercise in manipulating technical language.

Once the students have begun to acquire a certain amount of extra-linguistic background, they can be given a number of strategies for reducing specific texts to their underlying referents (this being, of course, the first leg of the translational trajectory). The first such strategy consists in exploiting the parallelism of textual structures and extra-linguistic orderings in order to derive information about the latter from the former. It is, in fact, quite common for entire texts to be structured, lexically and discursively, according to the properties of their extra-linguistic referents. A case in point is the chapter devoted to "La distribution" by J. Chagette (Technique automobile, T.I., le moteur : 89-93), the typographical features of which (more specifically, the headings corresponding to various levels of discursive units) were used to produce the tree structuring the field of engine types given above.

Such information may be conveyed less prominently ; in the following passage, it is distributed throughout the text proper :

Les massifs d'appuis s'appellent des piédroits quand ils ne reçoivent que des charges verticales (cas du massif commun à deux voûtes contiguës). Dans le cas des grandes vôtes des ponts ils s'appellent des piles. S'ils reçoivent aussi des charges horizontales ce sont des culées (cas du massif ne recevant qu'une voûte). (Quillet-Bâtiment, II : 302.)

Nonetheless, the structuring of the linguistic — and referential — fields emerges with the utmost clarity :

\begin{tabular}{|c|c|c|}
\hline \multicolumn{3}{|c|}{$\begin{array}{c}\text { massifs d'appuis } \\
\quad+\text { charge } \\
+ \text { verticale, } \pm \text { horizontale }\end{array}$} \\
\hline \multicolumn{2}{|c|}{ - horizontale } & + horizontale \\
\hline piédroits & piles & culées \\
\hline - ponts & + ponts & \pm pont \\
\hline
\end{tabular}

and the terms piédroit, pile and culée can be differentiated as bundles of relevant features :

$$
\begin{array}{ll}
\text { piédroit } & :- \text { horizontale, }- \text { pont } \\
\text { pile } & :- \text { horizontale, }+ \text { pont } \\
\text { culée } & : \text { - horizontale, } \pm \text { pont, }
\end{array}
$$

allowing the translator to deal with the lexical void created by the fact that the marker " \pm pont" is not relevant in English. 
Yet another strategy for reducing the technical text to its referents relies on the interaction between verbal and non-verbal syntagmata (see Part I above). In the following passage on vaults :

Une voute peut être:

- à extrados curviligne : l'extrados suit une courbe continue. Si l'épaisseur de la voûte est constante de la clef aux naissances, la voûte est à extrados parallèle.

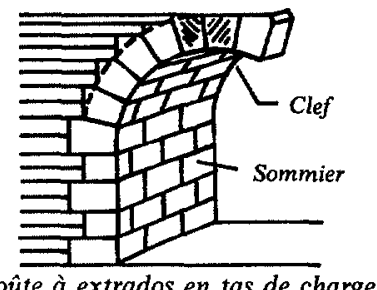

-à extrados en tas de charge : la ligne extérieure d'extrados est découpée en escalier,

- en berceau : l'intrados est une surface cylindrique. (Quillet-Bâtiment, II : 229.)

the precise message meaning or referential content of an item like curviligne will be established by determining what other lexical items the term enters into opposition with and, redundantly, within the visual system, what items the graphic equivalent of the term enters into opposition with.

The lexical structures of the passage are readily discerned : the opposition curviligne vs en tas de charge (vs en berceau) is given considerable prominence by a third semiotic system, the typographical layout, and is furthermore glossed in the metalinguistic segments of the text (suit une courbe continue vs est découpée en forme d'escalier) by the opposition continu vs découpé, which may be considered to be its distinctive features. The opposition between the abstract features continu vs découpé is, in turn, precisely what distinguishes the graphic items

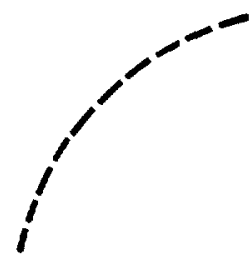

VS

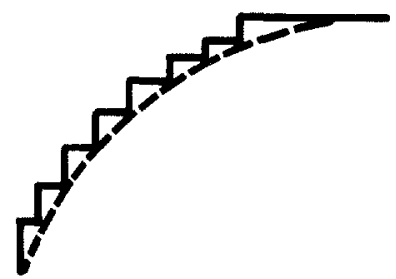

Recourse to para-textual systems is also the most effective way of establishing the precise meaning of an item like distribution in the text (Chagette, loc. cit.) referred to earlier. The term is polysemous, designating, en langue, three metonymically related referents : the function (timing), the assembly implementing this function (timing system or valve train) or a component of this assembly (the timing gear). This polysemia can be resolved only by determining what paradigms - textual and referential - the term and its referent enter into (clearly the function, assembly and component will have divergent distributions). Typographical features afford excellent paratextual equivalents of these referential paradigms. Thus, the chapter headings in the table of contents enumerate the items with which distribution forms a referential paradigm (cylindre, culasse, tuyauterie, carter, piston, bielle, vilebrequin, volant) and orient us towards the concrete meanings of the term (assembly or component as opposed to function). The headings of the various sub-divisions within the chapter present distribution as a syntagma 
(distribution à soupapes latérales/mixte/à soupapes en tête; $d$. à arbre à cames dans le carter/dans la culasse; $d$. à attaque indirecte/directe) and thus eliminate the meaning timing gear.

Yet another strategy for reducing the text to its underlying referents involves decoding it, both linguistically and referentially, by "opening up" or "developing" (in the geometrical sense) elliptical source-language formulations (generally nominalisations, and hence formulations with case gaps and other implications) to obtain paraphrases more explicitely descriptive of the referent. Thus, the syntagma lockup converter becomes, with sufficient knowledge of the referent, "a torque converter that locks up, i.e. in which impeller and turbine are locked together above certain speeds".

Similarly,

un dispositif de fixation d'un pignon d'entraînement des organes de distribution (Chagette : 73)

becomes

un dispositif sur lequel est fixé un pignon qui entraîne les organes qui distribuent (le mélange combustible) (aux cylindres) (au moment opportun).

This procedure is an iterative one, with feedback loops in which preliminary interpretations are tested against existing knowledge of the referent, then refined and retested, and additional information about the referent is sought. While certain case gaps can be filled through purely linguistic knowledge - thus the syntagma des organes can only be an objective genitive, "un pignon qui entraîne les organes", given the limited range of schemata base on entraîner (entraîner quelque chose) - others demand referential input, the injection of extra-linguistic information : "les organes qui distribuent (le mélange combustible) (aux cyclindres) (au moment opportun)". It is such knowledge alone that makes it possible to replace the polysemous (to the point of being referentially meaningless) $d e$ by prepositions more representative of the actual relationships involved (instrumentality/purpose/cause and effet, etc.) ${ }^{9}$ and to trace deverbals back to the sentences underlying them, supplying the subjects/objects/complements deleted in the process of nominalisation.

Once the nominalized form has been "developed" into a series of nested syntactic structures :

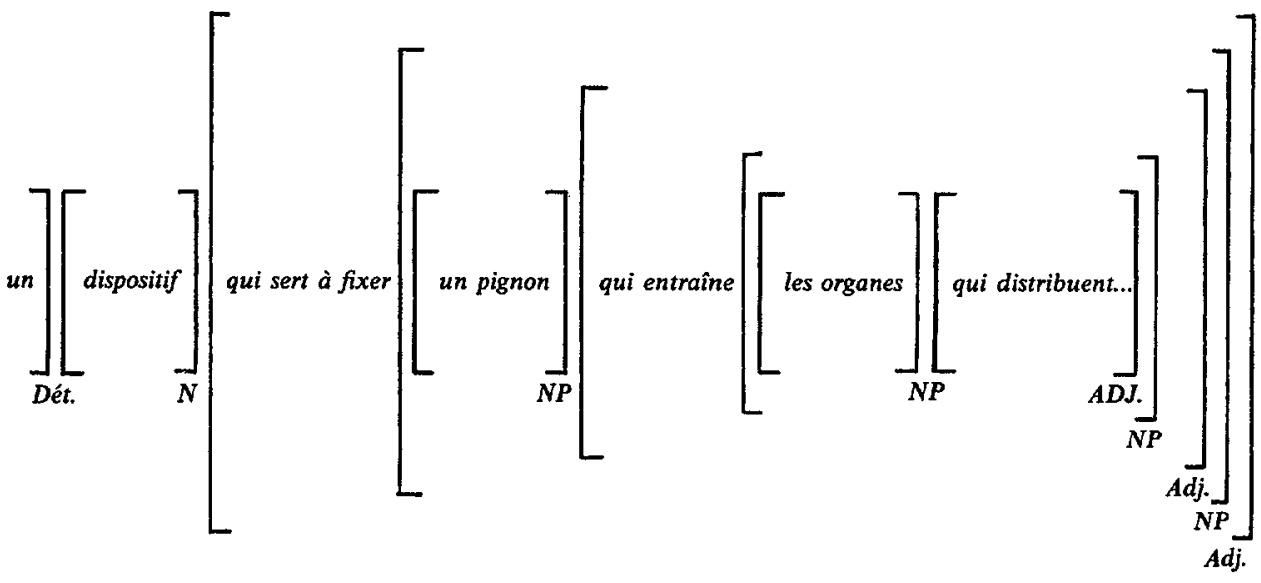

9. Cf., above, la pression des plateaux, which is rendered by the pressure exerted through the plates. 
it exhibits a much higher degree of cohesivity than would have been apparent at first glance. This syntactical cohesivity points to the existence of semantic and referential units : un $+\mathbf{N}+$ Adj. can only designate a specific referent, which, having been fully described by the paraphrase, has only to be identified and relabelled in the target language.

The recognition of semantic and referential units in turn leads automatically to the question of units of translation. And, in fact, with a little experience, the student will be able to isolate the standard syntagma dispositif de fixation (= dispositif qui sert à fixer) as a unit of translation and recognize that is maps into the English mounting. The problem now becomes one of decoding referentially and re-encoding linguistically the syntagma pignon + Adj. The thing described by this paraphrase must be identified referentially, through recourse to documentation, if necessary, before it can be re-labelled as timing gear (and the entire item translated as timing gear mounting) in English. involves :

The translational trajectory appropriate to such syntactically compact units thus

- developping the source-language syntagma to obtain a paraphrase more explicitely descriptive of the referent

- matching this paraphrase to the thing it describes ; recognizing referential and translational units

-relabelling the thing, thus described, in the target language.

Referential input is thus crucial in clarifying segments of the text whose compactness leads to the implicitation of certain case parameters. Such input - more specifically, knowledge of referential orderings - can also be used to correct faulty textual structures. In the passage on vaults reproduced above, the trichotomy set up, syntactically and typographically, between the terms à extrados curviligne/à extrados en tas de charge/en berceau is an incorrect one. Referentially, the correct structure is a binary one, the term extrados being conjunctive for the items curviligne and en tas de charge, and the disjunction occurring between extrados and intrados :

Une voûte peut être :

- à extrados curviligne ou en tas de charge

- à intrados en berceau ou [à pénétrations (case not envisaged in this text)]

The text should be rendered according to the referentially correct formulation.

In addition to its emphasis on extra-linguistic referents, the general approach has a metalinguistic focus : at the same time they are learning about things, the students must learn how to verbalize these things correctly in the target language (this being, of course, the second leg of the translational trajectory). Thus, the target-language register appropriate to the subject or subjects studied - i.e. both the terminology and the "support language" used to integrate this terminology into discursive structures - becomes itself one of the things dealt with in a course on technical translation.

In order to familiarize themselves as efficiently as possible with this register, students are advised to do all their background reading in the target language, as such readings will provide information regarding not only the extra-linguistic referents but also the way in which they should be verbalized in the target language. Accordingly, target-language texts must be viewed alternately as transparent utterances giving im- 
mediate access to the extra-linguistic and as entities in their own right, opaque constructions ${ }^{10}$ to be analyzed in terms of reproducible relevant features - in a word, as things.

The end point of this metalinguistic component is, of course, the manipulation of technical language, first in translation, eventually in technical writing. The latter is a natural outgrowth of the former, with, however, a difference that is crucial both in practice and from the pedagogical standpoint : the technical translator works with givens (pre-defined receiver and discursive structures) which are no longer givens in technical writing and must be adequately re-created. The student must learn not only to use the correct technical register but also to generate appropriate discursive structures and produce a text geared to a specific type of receiver. Initially, at least, his strategy may be view the structures of his text as being imposed by the referent. The text may thus be organized as an analogue of the referent, much like a diagramme or drawing of the latter ; like such a graphic substitute it should procede from a single, unified point of view and embody the same level of detail throughout (just as a diagrammatic representation will be drawn to the same scale throughout), with any eventual departures from the overall level of detail being suitably isolated (just as blowups have a special status in diagrams). In a word, the text, like the diagram, should be as accurate and informative as possible a substitute for the thing - or rather for those properties of the thing deemed relevant.

All of which brings us full circle. The utterances formulated as conceptual manipulations of things bear, inescapably, the imprint of their referents ; the technical text as thing derives its structures, both lexical and discursive, from the extra-textual thing it verbalizes.

\section{BIBLIOGRAPHY}

CHAGETTE, J. (1977) : Technique automobile, le Moteur, t. 1, Paris, Bordas.

Encyclopédie pratique de la construction et du bâtiment (1959) : [Quillet-Bâtiment], Paris, Librairie Aristide Quillet.

Encyclopédie des sciences industrielles Quillet : Mécanique - généralités, applications (1974) : [QuilletMécanique], Paris, Librairie Aristide Quillet.

LETHUILLIER, J. (1982) : "Évolution de la distribution dans les moteurs à combustion intermittente", Meta, 27-3 : 305-313.

Office de la langue française [OLF] (1979) : Vocabulaire de l'automobile, fascicule I : le Moteur, fascicule III : la Transmission, Montréal.

PINCHUK, I. (1977) : Scientific and Technical Translation, Boulder (Colorado), Westview Press.

ANNEX

BERCEAU, voute en

BARREL / TUNNEL / WAGON /

CRADLE vault (Sturgis III : 940)

BARREL (Aubert-Girdlestone : 106)

Definition :

- The simplest type of masonry or mass concrete vault. ... It is just an arch extended so that its width is comparable with, or more usually exceeds, its span (Guedes : 180-1)

- [may be] thought of as a semicircular arch projected horizontally in a direction at right angles to its span (Fitchen : 42)

- La voûte en berceau la plus simple ou berceau droit est constitué par un demi-cylindre droit posé sur un plan axial horizontal (Quillet II : 302b)

10. This means applying to technical texts the mode of reception characteristic of the potic text, the difference being that poetic texts are meant to be received in this fashion and depend on it for their esthetic effect, whereas the technincal text is meant to function quite differently, and becomes a thing in its own right only when viewed metalinguistically. 


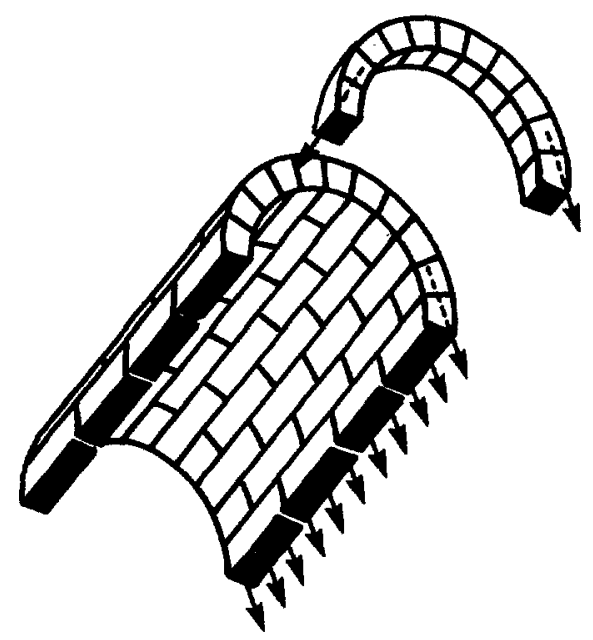

Semicircular Arch and Semicylindrical Vault

The diagonal thrusts, downward and outward from the crown, are indicated in shorthand fashion in the simple arch. These become "planes" of thrust in the barrel vault, which may be thought of as a simple arch projected horizontally at right angles to its span.

Fitchen 43

Typical collocations :

- In this search for stability, one of the most typical means of abutment for the continuous thrust of the nave's barrel vault came to be provided by continuous half-barrel vaults ramping from the thick outer walls of the side aisles, up to about the spring-line of the nave vault (Fitchen : 47)

- The early Romanesque vaults - semi-cylindrical or pointed barrel vaults, the ramping half-barrel vaults above side aisles, cloister vaults under towers, and of course the simple groin vaults of countless side aisles had all taken their shape from the projection of some generating arch (ibid., 63)

- ... barrels over nave and choir, semi-domes over apses and apsidioles, groins over crypt, narthex and aisles, except in Provence where quadrant vaults are used for these while a squinch dome crowns the crossing (Aubert-Girdlestone : 106)

\section{Derivatives}

half(-)barrel vaults (Sturgis III : 947 ; Fitchen : 47)

half barrels (Aubert-Girdlestone : 106)

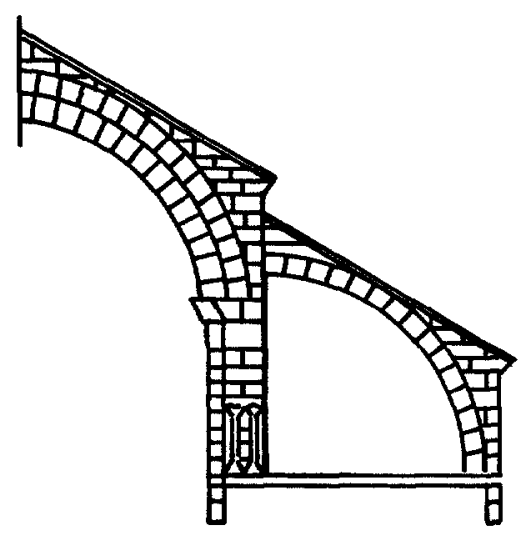


Typical collocations

... the use of half barrel vaults over aisles, or triforia, of churches, carrying solid stone roofs, and serving also as continuous flying buttresses resisting the outward thrust of the nave vaults (Sturgis III : 947)

\section{Oppositions}

barrel vault vs groin vault

\section{BIBLIOGRAPHY}

AUBERT, M. : Romanesque Cathedrals and Abbeys of France (translation by C. Girdlestone of Cathédrales, abbatiales, collégiales, prieurés romans de France).

DUBUISSON, B. (éd.) : Encyclopédie pratique de la construction et du bâtiment (Quillet).

FITCHEN, J. : The Construction of Gothic Cathedrals.

GUEDES, P. (ed.) : An Encyclopedia of Architectural Technology.

STURGIS, R. : A Dictionary of Architecture and Building. 